\title{
Language Anxiety in Teaching English and Its Solutions
}

\author{
Liwen Luo and Shufei Xu \\ Nanchang Teachers College, Foreign Language Department
}

\begin{abstract}
Keywords: Language anxiety; Affective filter hypothesis; Teaching English
\end{abstract}
\begin{abstract}
As the focus of research into a second language acquisition has been transferred from teachers to learners, more and more people begin to realize the important role of emotional factors on the success of a second language acquisition in the process of teaching foreign languages. During the teaching process, students' personality and interaction between teachers and students are more important than teaching methods. According to Krashen's affective filter hypothesis, during the process of learning a second language, learners will be subject to the influence of various emotional factors, among which anxiety is thought to be the most harmful. This paper explores the role of using emotional factors in teaching English on relieving students' language anxiety from the perspectives of students and teachers and provides specific suggestions to how to effectively and appropriately apply them in teaching, hoping students can experience the fun of learning English in a relatively relaxing and pleasant environment so as to achieve the goal of ultimately improving their English proficiency.
\end{abstract}

\section{Introduction}

Anxiety is individuals' emotional status of being nervous and feeling feared because they cannot achieve the desired goal or overcome threats, thus their self-esteem or confidence is harmed or they feel guilty or a strong sense of failure. Learners are subject to the impact of varying degrees of anxiety while learning a second language, and anxiety is an important emotional factor affecting the effect of learning a second language. During the process of learning a foreign language, different degrees or forms of anxiety affects learning effect with the former referring to a general trend of feeling anxious and an enduring trend of anxiety while the latter referring to anxiety shown in special scene or thing of learning a foreign language.

This paper explores how its application at college English classes helps to relieve students' language anxiety from the perspectives of teachers and students and compares the opinions of both college students and college English teachers to find that both teachers and students believe that free teaching plays an active role in relieving students' language anxiety, and compared with teachers, students are more acceptable to free teaching. In addition, in a free teaching atmosphere, students can have a deeper understanding of humorous teaching's role of relieving language anxiety.

\section{The Phenomenon of Language Anxiety}

Learning a foreign language is subject to the influence of various factors and linguists have proposed different opinions to explain these factors. Many researches indicate that learners' complicated dynamic emotional status influences the ability of concentrated learning, and it seems that learners need to focus on study in a safe and worry-free environment while anxiety is one of the important factors. Anxiety is a subjective emotion that can arouse tension, worry, fear and self-doubt. It can be divided into trait anxiety, state anxiety and situation-specific anxiety. Trait anxiety refers to a person's tendency to become more and more fixed in any situation. State anxiety refers to the feeling of anxiety at a particular time and in a particular situation. It is an unstable state, for example, before an exam. Situation-specific anxiety can be seen as a state anxiety that is confined to specific situations or particular events. The affective factors mainly include the motivation, attitude, self-confidence and anxiety of the learners. 


\section{Causes of Language Anxiety}

Internals Factors of Learners. Self-Esteem: Self-esteem is produced by self - appraisal, which reflects the degree of self - confidence. Less successful two language learners generally have lower self-esteem and language anxiety will have a negative impact on their language learning. Language anxiety has a positive effect on learners with high self-esteem, because they can work hard to adapt to the environment of language learning and overcome the anxiety.

Ambiguity Tolerance: Ambiguity tolerance refers to the degree of acceptance of the confusing situation. In the two language learning process, learners often have a sense of word, voice and other information correctly or not is not enough to grasp, these uncertainties will cause the anxiety of the learner. With the late in-depth study, these uncertainties will gradually clear. For example, when reading to skip unfamiliar words, the meaning of this article may be as understanding and answers.

Internal Factors. Social Communication: Social anxiety refers to the anxiety of people when they are evaluated by others in social situation or interpersonal relationship. Attaches great importance to the evaluation of others who tend to minimize the negative evaluation of the possible. In language learning in the classroom, the learner may have social anxiety to avoid embarrassment, afraid of making mistakes in front of the students, and tend to keep silent.

Identity and Cultural Shock: Recognizing a language group or target culture means the learners are a part of this group. Cultural shock can be shown as being frightened, helpless and reducing sense of identity. However, cultural shock can become the opportunity of cross-cultural learning through supplementing cultural cognition.

\section{Solutions to Language Anxiety}

Pay Attention to Behaviors at Class. In the course of teaching, the teacher's words and actions will cause students' anxiety. When answering a question from a student. Try not to stand beside the speaker, and make it prone to mood swings, easy to let the thought teachers and students focus on his (her) body, causing fear and self-confidence, anxiety. Teachers in the classroom teaching as little as possible even without criticism of students, otherwise, will enable students to produce a sense of depression, restrain the students' desire to use the target language, and cause anxiety. To encourage the students to look at the students, give a positive evaluation of the students have a sense of accomplishment, is conducive to the reduction of language anxiety.

Boost Students' Confidence in Learning Language. Encourage students to build up their confidence and believe in their ability to overcome anxiety. Although anxiety is a part of the individual characteristics of the two language learners, it can be overcome. To provide students with a chance to succeed, so that they are full of confidence and self-esteem, such as asking a few simple questions, do some simple conversation, etc. Clear teaching objectives, to help students find the realization of the goal of coping strategies, to achieve the goal of self-confidence.

Coordinating Psychology and Emotions of Teachers and Students at Class. Create a relaxing, natural and harmonious class atmosphere. The classroom between teachers and students emotional coordination, classroom teaching is an important part, is the key to success. Individual mood adjustment at any time in the process of teaching, with an optimistic, confident and cheerful mood to face the students, so that students can feel happy and interested in learning. The equality between teachers and students get into the students, understand students, to participate in the activities of the students, reduce or even eliminate the tension of students to teachers, students answer questions will help reduce anxiety.

\section{Conclusion}

Language anxiety will directly affect communication and daily teaching in reality and it is caused by internal and external factors. In this paper according to the actual situation to solve language anxiety phenomenon, requires teachers should care about students, early detection anxiety of students, early give students to help teachers to on foreign language learning anxiety and the 
emotional factors give enough attention, attention should be paid to the observation of manners, found at the foreign language classroom learning anxiety of students, their classroom anxiety to a minimum, so as to improve the students' English learning achievement.

\section{References}

[1] Macwan M J. Problems Of Teaching English And Its Solutions [J]. Review of Research, 2012, I (IV).

[2] Jiang Z F. On Anxiety of Oral English Language Learning for College Students in Minority Areas of West China and Relevant Solutions [J]. Journal of Guangxi Teachers Education University, 2009.

[3] Wang S Y. On Current Situation of Primary English Teaching in Countryside and Its Solutions [J]. Journal of Liupanshui Teachers College, 2011.

[4] Önem E, İclal Ergenç. Testing a model of teaching for anxiety and success for English language teaching [J]. Cambridge Journal of Education, 2013, 43(3):357-376.

[5] Kamis A, Stern T, Ladik D M. A flow-based model of web site intentions when users customize products in business-to-consumer electronic commerce [J]. Information Systems Frontiers, 2010, 12(2):157-168.

[6] Schmid E C. Interactive Whiteboards and the Normalization of CALL [J]. Handbook of Research on E-Learning Methodologies for Language Acquisition, 2003.

[7] Eppler M J, Mengis J. The Natural History of Professions and Its Effects on Property Valuation in the UK and Germany [J]. Eres, 1997, 38(1):325-344.

[8] Kruger-Ross M J, Farwell T M. Risky Media: Using Subversive Technologies in Education to Question Assumptions about Power, Teaching, and Assessment [J]. Social Media in Higher Education Teaching in Web, 2013.

[9] Doherty I. Achieving Excellence in Teaching: A Case Study in Embedding Professional Development for Teaching within a Research-Intensive University [J]. Cases on Quality Teaching Practices in Higher Education, 2013.

[10] Tarnittanakorn N. An analysis of the relationship between CRM and the success of micro e-commerce enterprises in Thailand.[J]. Review of Business Research, 2011, : 11(:2).

[11] Esposito A N, Garrett G. Method and system for conducting real time electronic commerce: US, US 6587838 B1 [P]. 2003.

[12]Bottles K. The information revolution: opportunities and pitfalls for patients and providers. (Health Care Meets E-Commerce).[J]. Americancollegeofphysicianexecutives, 2000, : 26(:1). 